\title{
ECSTASY INTOXICATION: THE TOXICOLOGICAL BASIS FOR TREATMENT
}

\author{
Maristela Ferigolo, Adriana G. da S. Machado, Niara B. Oliveira and Helena M. T. \\ Barros
}

FERIGOLO M et al. - Ecstasy intoxication: the toxicological basis for treatment. Rev. Hosp. Clín. Fac. Med. S. Paulo 58(6):332-341, 2003.

Youngsters are increasingly using 3,4 methylenedioxymethamphetamine, known as ecstasy, because it is wrongly believed that it does not induce harm. However, there are many reports of adverse effects, including acute intoxication, abuse potential, and possible neurotoxic effects. Therefore, health care providers need to promptly recognize the symptoms of systemic intoxication in order to initiate early treatment. The drug is used by the oral route for long hours during crowded dance parties. Acutely, ecstasy increases the release of serotonin and decreases its reuptake, leading to hypertension, hyperthermia, trismus, and vomiting. There is debate on whether recreational doses of ecstasy cause permanent damage to human serotonergic neurons. Ecstasy users showed a high risk of developing psychopathological disturbances. The prolonged use of ecstasy might induce dependence, characterized by tolerance and hangover. Acute ecstasy intoxication needs emergency-type treatment to avoid the dose-dependent increase in adverse reactions and in severity of complications. There are no specific antidotes to be used during acute intoxication. Supportive measures and medical treatment for each one of the complications should be implemented, keeping in mind that symptoms originate mainly from the central nervous system and the cardiovascular system.

DESCRIPTORS: 3,4 methylenedioxymethamphetamine. Adverse effects. Substance-related disorders. Cognition. Hyperthermia.

In 2001, an estimated 8.1 million (3.6\%) Americans aged 12 or older had tried ecstasy at least once in their lifetimes. This is more than the estimated 6.5 million $(2.9 \%)$ lifetime users in $2000^{1}$. The Brazilian National Household Survey on Psychoactive Drug Use detected that $0.6 \%$ of respondents aged 12 or older used ecstasy or other hallucinogens, meaning that 295,000 Brazilians used this group of drugs at least once in their lifetimes ${ }^{2}$.

Ecstasy or 3,4 methylenedioxymethamphetamine (MDMA) is a synthetic amphetamine ${ }^{3-5}$, the widespread use of which since the 1980s might be related to the exaggerated declaration of possible therapeutic effects by some authors ${ }^{6}$. This drug is also known as XTC, E, Adam, MDM or " drug of love" fects of increased self-confidence, understanding and empathy, and an increased sensation of proximity and intimacy with other people are described mainly in uncontrolled studies. Communication and personal relationship skills were also described to improve. Euphoria and increased emotional and physical energy are presumed to occur with this psychostimulant ${ }^{8-11}$. Since the

From the Psychoactive Substances Information Service, Division of Pharmacology, "Fundação Faculdade Federal de Ciências Médicas de Porto Alegre"- Porto Alegre/RS, Brazil. Received for publication on June 16, 2003. subjective effects of MDMA in humans are not the same as those produced by LSD and because the drug does not have a similar structure or pharmacological activity to hallucinogens or psychedelic drugs, the term "entactogens" meaning "entering in contact with yourself" 10,11 was proposed to define a new pharmacological class. Also, a never-proven sexual enhancement action was cited by experimental consumers ${ }^{12,13}$. However, ecstasy does not increase the excitement or the sexual desire in most of the users, and orgasms may be delayed due to higher awareness of sensory input, especially in men; it cannot be classified as an agent to treat sexual dysfuctions $^{12}$. Ecstasy can be more 
easily classified as a psychostimulant, since it has chemical and action similarities with cocaine and amphetamines. According to the American Psychiatric Association, ecstasy may be classified as a hallucinogen, due to its potential to occasionally induce hallucinations and "flashbacks" if used in extremely high doses ${ }^{14}$. Certainly, in the coming years, a better understanding of the drug's effects will allow its accurate classification.

Nowadays, MDMA is becoming the center of discussion in both lay and scientific press for its abuse potential and possible neurotoxic effects. In the beginning of the 1990s, it was banned as a therapeutic drug by the World Health Organization ${ }^{15}$. Ecstasy was introduced in Brazil around 1994. Since 1997, ecstasy has been a topic of questioning for drug hot lines in Brazil ${ }^{16}$. In Brazil, ecstasy is sold at all-night dance parties attended by hundreds of thousands of youngsters where loud techno music is played, and bright and pulsating lights fill the environment. There is evidence that until now, the use of ecstasy has been limited to middle-class or upper-middle-class individuals in Brazil, so that most people, including health care professionals, are unfamiliar with the drug. However, ecstasy may be becoming more popular in Latin America, following the pattern seen in North America and Europe. The fact that ecstasy is sold as a pill and is thus extremely easy to use is a possible contributing factor to the drug's popularity ${ }^{17}$. In a recent survey in the city of São Paulo, most ecstasy users were shown to have attended universities and use dance party events and the Internet for entertainment. These individuals are equally distributed in heterosexual and homosexual groups, with respect to sexual orientation, and most of them use piercing and tattoos. According to these individuals, the experimental use of the drug occurred due to its easy acquisition ${ }^{18}$.
In Northern Hemisphere countries, adolescents with a polydrug-use pattern also consume ecstasy. The substance is introduced later in a drug-use sequence of legal and illegal substances. The pattern of ecstasy use differs from the use of amphetamines; it is strongly associated with subcultural music preferences and house-party going and weakly associated with smoking and conduct problems ${ }^{19}$. Its use is increasing in college students who also use marijuana, alcohol, have multiple sex partners, and spend more time socializing than studying ${ }^{20}$. Gay/bisexual men who are MDMA users (13\% of the group) were found to be younger, less educated, to have had more male partners, more one night stands with men, to have unprotected anal sex with males, to have more gay/ bisexual friends, and to have higher levels of gay community participation and affiliation than nonusers ${ }^{21}$.

Ecstasy has a reputation of being a safe drug; however, there are many reports of adverse reactions associated with the drug, as described in other reviews $^{3,22,16,23,24}$. The increasing popularity of ecstasy among youngsters prompts the need for health care providers to quickly recognize the symptoms of severe systemic intoxication in order to initiate early treatment, with rehydration and cooling in cases of hyperthermia, for seizures, cardiac arrhythmia, and for metabolic and electrolyte abnormalities. The need for more information on ecstasy seems to be growing due to its increased use, detectable by the higher number of reports of intoxication with ecstasy. Therefore, the objective of this review is to give a recent picture of the clinical effects of the drug and the consequences of drug use. We also reviewed some preclinical studies performed with experimental animals to elucidate clinical problem mechanisms and discuss future prevention methods for long-term adverse outcomes of ecstasy.

\section{PATTERNS OF ECSTASY USE}

Ecstasy was synthesized and patented in Germany by Merck in 1914 for appetite control. However, it was never released in the market ${ }^{22}$, and the scientific community ignored it until 1970. At that time, ecstasy was reported to produce "a controllable state of alteration of conscience with sensual and emotional harmony", suggesting that it could be used as an adjuvant in psychotherapy ${ }^{8,9,25}$. In the beginning of the 1980s, MDMA became popular as a recreational drug ${ }^{26,27}$. Around 1985, the USA Drug Enforcement Administration (DEA) restricted the therapeutic use of MDMA, placing it on the list of forbidden substances and without clinical use due to its frequent abuse and to central nervous system serotonergic degeneration $^{22,24,28,29}$. Due to the expansion of the illegal drug market and the belief that the use of ecstasy for recreational purpose is safe, the number of cases of toxicity related to ecstasy or to a mixture of substances sold as ecstasy has been increasing ${ }^{6}$. However, several scientific reports confirm that ecstasy is potentially fatal, and therefore, precautions should be taken to avoid the beginning of its use by children and adolescents ${ }^{30,31}$.

Ecstasy is used orally and is sold as tablets or capsules of several colors, shapes, and sizes, containing from 50 to $150 \mathrm{mg}$ of the drug. Sometimes it is sold as a powdered substance to be mixed with beverages ${ }^{6,32,33}$. There are descriptions of rectal use and intranasal use of the powdered MDMA ${ }^{34}$. The street preparations are up to $90 \%$ pure $^{34}$ and may also contain MDA, caffeine, LSD, amphetamine, methamphetamine, mixture of amphetamines, paracetamol, or ketamine and other nonidentified substances $^{34,35}$. Therefore, since quality control does not exist in the illicit drug market, consumers are subject to additional risk. When the typical recrea- 
tional doses are used, MDMA is not frankly hallucinogenic ${ }^{24,26}$. Changes in perception and hallucinations occur in big gatherings. The typical dose for recreational purpose is 70 to $150 \mathrm{mg}$, corresponding to 1 or 2 capsules or tablets. Dose supplements of 50 to $100 \mathrm{mg}$ may be taken every 30 minutes $^{18,24}$ due to the expectation of increasing the intensity of the experience ${ }^{34}$. In Brazil, most individuals use up to 1 tablet per night chronically, however a few of them reported the use of more than 3 tablets per night ${ }^{18}$. The recreational use of ecstasy is done more frequently during weekends in dance clubs or parties where crowds dance vigorously. Raves, meaning delirium or fury, are all-night dance parties attended by a large number of people, sometimes exceeding 20,000. The rave scene is international and may be accompanied by clandestine activities, hypnotic electronic music, and the liberal use of drugs (marijuana, alcohol, cocaine, heroin, gamma-hydroxybutyrate, and ketamine) in addition to ecstasy $y^{20,21,36-}$ 39. Therefore, raves accumulate conditions that induce or increase the number of toxic or lethal cases induced by ecstasy because they are crowded, very noisy, and may develop high environmental temperatures ${ }^{23,33}$. Most of the patients with serious ecstasy intoxication present dehydration, fainting, or convulsions, and they frequently need treatment at hospital emergency departments $^{37}$. Because of that, in some places where youngsters go to get the drug and to party, the "drug agencies" are specially prepared to assist ecstasy users and to minimize the adverse effects accompanying drug use ${ }^{16}$.

The recreational use of ecstasy began among North American students, and its consumption has been increasing in Spain, Italy, England, and in countries of Latin America ${ }^{6,16,40}$. It is used in environments where the consumption of cocaine and alcohol is also prevalent ${ }^{34,41}$. Students, house- wives, merchants, health professionals, and writers, as well as unemployed individuals have been motivated by curiosity to start ecstasy use ${ }^{34}$. The increase of the recreational use of MDMA by youth is well documented; however, reports about ecstasy effects in children do not exist ${ }^{30}$. Accurate estimates of the prevalence and incidence of ecstasy use are still under scrutiny in several countries.

The pattern of ecstasy use is rather uncommon when compared to the use pattern of other substances. The recreational use is frequently spaced by 2 to 3 weeks. One of the reasons for this pattern might be that the pleasant effects of the drug seem to decrease at the same time as the "negative effects " increase if 5 or more doses of the drug are used frequently. In the 1980s, MDMA was used less than twice per month, and most individuals had lower than 10 drug experiences in their entire lifetime ${ }^{34}$. More recently, higher frequency of drug use is already being described with individual cases of daily and intense use of ecstasy ${ }^{18,24}$. This can be seen in the Brazilian population, since half of the ecstasy users in São Paulo report the use of ecstasy on 5 to 50 different occasions, while around one-third of the interviewees reported the use of ecstasy on 50 to 500 occasions $^{18}$.

\section{TOXICOKINETICS}

There is incomplete knowledge about the pharmacological properties of MDMA in humans, since the studies are difficult to perform because of ethical issues ${ }^{22,42}$. Only case reports ${ }^{43}$ and small randomized double-blind clinical studies ${ }^{42}$ among healthy people using small to moderate doses of ecstasy are reported. The psychostimulant effects of MDMA are observed 20 to 60 minutes after the ingestion of moderate doses of ecstasy, 75 to 100 $\mathrm{mg}$ and last from 2 to 4 hours $^{3,26}$. Peak ecstasy plasma levels occur 2 hours after oral administration, and residual levels of $0.005 \mathrm{mg} / \mathrm{L}$ are found after 24 hours from the last $\operatorname{dos}^{42,43}$. The oral dose of $50 \mathrm{mg}$ of ecstasy produces a maximum plasma level of $0.11 \mathrm{mg} / \mathrm{L}$, $75 \mathrm{mg}$ produces a level of $0.13 \mathrm{mg} / \mathrm{L}$, and $125 \mathrm{mg}$ produces a level of 0.23 $\mathrm{mg} / \mathrm{L}$. There is lack of data on the percent of oral absorption of MDMA ${ }^{22}$.

The area under the curve (AUC) of plasma concentrations of ecstasy is $0.99 \mathrm{mg} / \mathrm{L}$ after $50 \mathrm{mg}$ and may reach $2.2 \mathrm{mg} / \mathrm{L}$ after $125 \mathrm{mg}$. The consumption of several capsules of ecstasy causes drug plasma levels up to around $7.72 \mathrm{mg} / \mathrm{L}$. More than 40 tablets of ecstasy are described to have been used in some of the overdose cases and produced plasma levels 6 to 70 times higher than this ${ }^{37}$. The AUC describes the concentration of the drug in plasma as a function of time and suggests that MDMA has a non-linear pharmacokinetic profile; consumption of elevated doses of the substance may produce disproportional elevation of plasma levels of ecstasy ${ }^{5,42}$.

MDMA or ecstasy is widely distributed in the mammalian organism, easily crossing membranes and the bloodbrain barrier. The amount of drug binding to plasma proteins is unknown ${ }^{22}$. Its clearance depends partially on liver metabolism, $3 \%$ to $7 \%$ become the active substance MDA, and $28 \%$ is biotransformed to other metabolites. Around $65 \%$ of the dose is eliminated without being metabolized through the kidneys ${ }^{42,43}$. As with all amines, urinary excretion depends on the urinary $\mathrm{pH}$. Acidification of urine increases drug elimination, which could be applied to speed drug clearance during intoxication ${ }^{22}$. However, acidification is rarely recommended due to the risk of worsening nephrotoxicity by myoglobinuria ${ }^{44}$.

The plasma half-life of ecstasy is 7.6 hours. This information is very rel- 
evant when treating intoxication, because 6 to 8 half-lives are necessary to complete depuration of the drug; therefore, about 48 hours would be necessary for the complete elimination of ecstasy. It can also be foreseen that for a plasma level of $8 \mathrm{mg} / \mathrm{L}$, which is considered to be the severe intoxication level, about 24 hours would be necessary to decrease to a plasma level lower than $1 \mathrm{mg} / \mathrm{L}$, which produces much less clinical effects. Therefore, this would be the estimated time of intensive care needed by intoxicated patients who used a few ecstasy capsules. However, this time would be longer when a higher number of tablets are consumed, since drug depuration is not linear.

\section{ACUTE AND CHRONIC BEHAVIORAL EFFECTS}

The neuropsychiatric effects induced by ecstasy may be classified into different categories. The acute subjective effects are altered perception of time and changes in visual perception, increased self-confidence, understanding and empathy with decreased defensiveness and aggression, and increased social interactions. Communication and personal relationship skills were also described to improve. Increased emotional and physical "energy" is presumed to occur with this psychostimulant; however, there is decreased ability and less desire to perform mental or physical tasks. Euphoria, decreased sleep, appetite, fatigue, depressed mood, and decreased anxiety are described as short-term effects ${ }^{10,11,15,25,28}$. Other central nervous system effects range from euphoria, central nervous stimulation, and feelings of closeness to mild hallucinations, impairment of cognition and coordination, and more serious reactions like agitation, disturbed and bizarre behavior, and possibly psychosis.
When the typical recreational doses are used, MDMA is not frankly hallucinogenic $^{24,26}$. Changes in perception and hallucinations occur in cases of intoxication with higher doses of 300 $\mathrm{mg}$ or more ${ }^{34}$. These hallucinations are similar to those produced by mescaline. Initially, visual hallucinations are in black and white and later become colorful. Modification of body perception with sensation of depersonalization, confusion, illusions, and sensation of lightness or flotation may occur $^{34}$. In addition to these behavioral effects, symptoms include trismus, bruxism, nystagmus, motor tics, restlessness, headaches, and anxiety ${ }^{45}$. The most frequently perceived adverse effects are decreased desire to execute physical and mental tasks $(70 \%)$, decreased appetite $(65 \%)$, and trismus $(50 \%)^{15}$. It must be assumed that the risk of being involved in traffic accidents during MDMA use is increased. The prevalence of detectable MDMA blood levels indicate an increased risk of reckless driving comparable to that observed after the use of amphetamine $^{46}$

Psychopathologies associated with the use of MDMA are classified as acute, when occurring in the first 24 hours after drug use, subacute when occurring 24 hours to 1 month after drug ingestion, and chronic if they occur after a month of drug use ${ }^{24,45}$. The most frequent acute complications include anxiety, insomnia, flashbacks, panic attacks, and psychotic spells ${ }^{48,49,50}$. Those who have acute paranoid psychotic reactions after taking MDMA may become violent and are likely to react in the same way when taking the drug again ${ }^{51}$. The subacute complications include depression, dizziness, anxiety, and irritability. MDMA consumers are found to be at high risk of developing psychopathological disturbances, mainly flashbacks, depression, psychotic disorders, cognitive disturbances, bulimic episodes, impulse control disorders, panic disorders, and social phobia $^{48,49,52}$. The cases of paranoid psychosis after abuse of MDMA show that there is an organic disorder secondary to the neurotoxic effect of MDMA rather than a temporary functional mental disorder ${ }^{53}$. Depression in ecstasy patients could be related to serotonergic function as measured through PET scans ${ }^{54}$. In fact, weekend use of MDMA may lead to mid-week depressed mood, and the possible mechanism underlying the behavioral changes includes temporary depletion of serotonin, due to serotonergic neurotoxity ${ }^{55}$.

For 10 years, ecstasy has been recognized as inducing psychological dependence after daily use of high doses for prolonged time ${ }^{34}$. Physiological dependence is not yet recognized because "craving" or withdrawal syndrome was not described ${ }^{34}$. However, based on the diagnostic criteria for substance dependence by the American Psychiatric Association ${ }^{14}$, physiological dependence by ecstasy should be kept in mind. Actually, the prolonged use of ecstasy fulfills 4 dependence criteria: it is used in larger doses than the ones initially planned ${ }^{56}$; it is used in spite of the knowledge of the adverse effects, it produces a hangover characterized by insomnia and fatigue $^{57}$; and it may induce tolerance ${ }^{48}$. Tolerance to the psychoactive properties of MDMA develops rapidly, and there are some individuals who use increasing amounts of ecstasy to reinforce the psychoactive effect ${ }^{18,48}$. In some individuals, tolerance occurs to some of the pleasant psychoactive effects of ecstasy but not to the physical effects, and the dose increase may produce dysphoria ${ }^{26}$. In this group of individuals, MDMA does not cause dependence, and the use of very large amounts of ecstasy, for a long period is $\operatorname{rare}^{56}$. It is still necessary to define which are the social, genetic, cultural, 
environmental, and hormonal factors involved in these long-term individual differences in ecstasy's effects.

Perhaps the most disturbing aspect of ecstasy effects is the risk of irreversible long-term neuropsychiatric effects $^{33}$. MDMA is neurotoxic to serotonergic neurons of different animal species $^{13}$, although there is debate on whether recreational doses of ecstasy may cause permanent damage to the human brain ${ }^{33,56}$. In very recent publications, several authors presented evidence that ecstasy might be neurotoxic to humans ${ }^{58,59,60,61,62}$.

Cognitive performance may be affected in drug-free recreational ecstasy users, with reduced memory for new information, impaired higher executive processing, and heightened impulsivity. Some ecstasy users also complain of poor memory and/or concentration difficulties, which they attribute to the previous MDMA use. This particular pattern of cognitive decrement in humans is consistent with the animal data showing serotonergic damage following MDMA administration, accompanied by impulsivity, higher cognitive impairment, and memory deficit ${ }^{58}$.

In fact, ecstasy users showed a broad pattern of statistically significant, but clinically small, impairment of memory as measured by direct recall and recognition and prolonged reaction times that are accompanied by changes in cortisol plasma levels. Heavy users were more affected than moderate users ${ }^{63}$. Significant impairment was found on measures of verbal memory and of delayed memory in ecstasy users. However performance was similar across all parameters for visual reaction time, auditory reaction time, complex reaction time, visual memory, and attention and concentration. There is, therefore, evidence for long-term neuropsychological sequelae associated with the use of ecstasy, particularly with regard to delayed memory ability ${ }^{59}$. Users processed information as quickly as nonusers but less accurately ${ }^{60}$. Ecstasy users were unimpaired in simple tests of attention (alertness), but performed worse than nonusers in more complex attention tests, in memory and learning tasks, and in tasks reflecting aspects of general intelligence. Heavy ecstasy use and combination with cannabis is associated with poorer performance by the group of ecstasy users ${ }^{61}$.

There is ecstasy-related 5-HT neural injury associated with the functional sequelae of ecstasy users described above. In particular, ecstasy users have selective decrements in cerebrospinal fluid 5-hydroxyindoleacetic acid and a decreased number of brain serotonin transporters, similar to nonhuman primates with documented MDMA-induced neurotoxicity $^{62}$. Therefore, the neurochemical data provide evidence that MDMA is neurotoxic to brain serotonin neurons in humans, and the behavioral data suggests that brain serotonin injury is associated with subtle, but significant, cognitive deficits ${ }^{64}$.

\section{MECHANISMS OF TOXICITY}

Probably, a sole mechanism of action is insufficient to explain all effects induced by ecstasy. Due to its complex activity spectrum, its effects on human behavior can be related to several neurochemical processes involving serotonin, dopamine, and norepinephrine $e^{8,10}$, similarly to what is seen with other amphetamines ${ }^{13}$. However, serotonin plays the main role in ecstasy effects ${ }^{22,65,66}$.

There is an extensive body of data demonstrating that ecstasy produces toxic effects on brain serotonin neurons in animals within the dose range of recreational MDMA users due to type 2 vesicular monoamine transporter reduction ${ }^{67}$. The serotonin trans- porter was significantly reduced in the mesencephalon and the thalamus of ecstasy users when compared with drug-naive subjects. The distribution volume ratios of the serotonin transporter in former ecstasy users were very similar to drug-naive subjects in all brain regions, indicating protracted but reversible lesions of the serotonin transporter by $\mathrm{PET}^{68}$.

\section{DIAGNOSIS AND TREATMENT OF ACUTE INTOXICATION WITH ECSTASY}

The well-known risks of adverse reactions to ecstasy and their probable mechanisms are summarized in table 1. The intensity of the adverse events depends on the dose, the frequency of use, and on individual variation. It is still not clear why some people use the drug regularly without adverse outcomes, while others present severe toxic responses ${ }^{35}$. One of the possibilities is that there might be differences in effects at the first experience with the drug or at a new acute episode following previous experiences with the drug. These adverse events may be acute, residual, or persistent. The acute adverse effect may occur after the use of low doses and may disappear in 24 hours. Overdose acute reactions occur at indeterminate dosages, and have been described to occur after the intake of 1 to 42 capsules of ecstasy. Residual effects have a hangover time course, while persistent effects last for up to 2 weeks. Gender differences in effects are expected to be described, because it is recognized that there are more neurochemical effects of ecstasy on females ${ }^{69}$, but epidemiological studies still do not provide evidence that they are at higher risk than males when using similar ecstasy doses.

Symptoms to be treated originate mainly from the central nervous system and the cardiovascular system. 
Table 1 - Ecstasy behavioral effects after use of moderate doses or after repetitive intake and their probable neurotransmitter mechanisms.

\begin{tabular}{|c|c|c|}
\hline Patterns of use & Acute doses & Repetitive intake \\
\hline Acute (low doses) effects & $\begin{array}{l}\text { tachycardia }^{1} \text {, hypertension } \\
\end{array}$ & $\begin{array}{l}\text { vomiting }^{2} \text {, ataxia, nystagmus visual } \\
\text { allucination }{ }^{2} \text {, paresis/ paresthesia of } \\
\text { extremities, increased cold sensitivity } \\
\text { (may also occur in the first experience } \\
\text { with high dose) }\end{array}$ \\
\hline Overdose reactions & $\begin{array}{l}\text { cardiac arrhythmias }{ }^{1}, \text { tachycardia }^{1} \text {, palpitations }{ }^{1} \text {, hypertension } \\
\text { and subsequent hypotension }{ }^{1}, \text { hyperthermia }^{2} \text {, increased } \\
\text { muscular tonus, visual allucinations }{ }^{2} \text {, hepatotoxicity }{ }^{4} \text {, acute } \\
\text { renal failure, disseminated intravascular coagulation }{ }^{1} \text {, } \\
\text { rhabdomyolysis, death }\end{array}$ & $\begin{array}{l}\text { screams }^{3} \\
\text { toxic hepatites }\end{array}$ \\
\hline
\end{tabular}

Residual effects

insomnia $^{1}$, muscle aches, fatigue ${ }^{5}$, lightheadedness

Persistent effects

fatigue $^{5}$, depression ${ }^{5}$, nausea ${ }^{2}$, flashback ${ }^{2}$

panic and anxiety attacks ${ }^{2}$, persistent insomnia $^{1}$, psychosis $^{3}$, loss of weight ${ }^{1,2}$, irritability $^{3}$

Noradrenergic effects ${ }^{1}$; Serotonergic stimulation ${ }^{2}$; Serotonergic deficiency ${ }^{3}$; Idiosyncrasy ${ }^{4}$; Noradrenergic/Serotonergic deficiency ${ }^{5}$.

Death due to ecstasy overdose is associated with arrhythmia or hyperten$\operatorname{sion}^{8,32,37}$ and may be associated with acute bronchospasm, allergic reactions, malignant hyperthermia, convulsions, disseminated intravascular coagulation, rhabdomyolysis, and acute renal failure ${ }^{32,71,72}$ or hepatotoxicity ${ }^{73}$. The estimated interval between drug use and death varies between 2 and 60 hours ${ }^{6,30,73}$.

When treating an intoxicated patient, confirmation of the agent involved should be sought. The analysis of suspicious substances (powder samples) or of corporal fluids (serum, urinates, aspired gastric) can be accomplished by thin layer chromatography, gaseous chromatography, ultraviolet and infrared spectrophotometry or flame ionization ${ }^{32,57}$. Based on the halflife of the drug and time of renal elimination of ecstasy, the biological material should be collected at least in the first 72 hours from the beginning of the intoxication disorder. Among the general laboratory tests needed for patients intoxicated with ecstasy are hematological assessment, because MDMA is involved in the suppression of bone marrow, and electrolytic as- sessment to evaluate the degree of dehydratation ${ }^{70}$.

Acute severe ecstasy intoxication requires effective and quick treatment to avoid the dose-dependent increase in frequency of adverse reactions and to prevent severe complications. It still must be determined whether antagonist agents acting at serotonergic, noradrenergic, or dopaminergic sites will have beneficial effects if used to reverse the drug effects. Currently, specific antidotes against ecstasy are not available $e^{33}$, and similar treatment protocols to the ones used for amphetamine or cocaine intoxication are proposed. Basically, ventilatory and cardiovascular support and appropriate treatment for each one of the complications should be implemented.

Ventilatory support to maintain the airway and evaluation of body temperature and decrease of body temperature if necessary are the first measures to be implemented in ecstasy intoxication. Hyperthermia may be prevented $^{33}$. Heavy and frequent recreational users of MDMA may have impaired thermoregulation as demonstrated in preclinical studies, and thus may be at greater risk for acute adverse response to MDMA in a hot, crowded dance environment ${ }^{74}$. Thermoregulation of individuals on ecstasy is labile and much more dependent on environmental conditions. Serotonergic antagonists, such as ketanserin or methysergide, or haloperidol may be needed to stabilize body temperature; however, neuroleptics must be used with extreme care, because they may also cause hyperthermia ${ }^{23}$. Selective or not selective reuptake inhibitors of serotonin, such as tricyclic antidepressants, fluoxetine, or citalopram are formally contraindicated because they enhance the effects of serotonin release and decrease the seizure threshold ${ }^{23}$.

Rehydration might be necessary and should be done with caution due to the risk of water intoxication. To decrease muscular activity and for seizure treatment and decrease of agitation or anxiety, midazolam, diazepam, or lorazepam should be given through IV administration. The use of dantrolene as a muscular relaxant may be necessary ${ }^{33,71}$. Clomethiazole is used in England in the treatment of the acute toxicity of the drug because of its action at GABA receptors, with further antagonism of the serotonergic syn- 
drome and antiseizure activity ${ }^{23}$. However, it is not available worldwide. Haloperidol also attenuates ecstasy-induced mania but has no reducing effect on other subjective changes or on cardiovascular effects ${ }^{4}$.

Emesis is contraindicated, due to the risk of inducing seizures in these patients, but gastric lavage and administration of activated coal and a cathartic may be indicated ${ }^{44}$. Chewing gum counteracts jaw-clenching ${ }^{33}$. As already pointed out, acidification of urine to increase drug excretion is rarely recommended due to the risk of worsening the nephrotoxicity induced by myoglobinuria ${ }^{44}$. Hypertension and tachycardia may be temporary in mild cases. For moderate intoxications, sedatives or oral nifedipine will be needed ${ }^{44}$. Otherwise, patients may be treated with vasodilators, phentolamine, or nitroprusside $^{44}$. Arrhythmias are treated with propranolol or esmolol; however, to avoid paradoxical hypertension or coronary insufficiency, labetalol might be preferred. Hypotensive patients need fluid reposition or vasoconstrictors ${ }^{44}$.

\section{CONCLUSION}

It is known that primary and secondary prevention of drug abuse is fundamentally based on information. Knowing about the dangerous effects of a drug is the first step in avoiding drug abuse. Recognizing and promptly treating acute intoxication prevents further damage. In spite of it not being a new drug, the great majority of health professionals do not know the effects and possible complications of ecstasy use. There is international concern that ecstasy has the potential to be the worst drug of the 21 st century, according to the Organization of the United Nation. In Brazil, the Fed- eral Council of Narcotics did not detect the local production of the drug, and the responsible organizations are still determining the best approach for combating its trafficking.

This review was sought with the increasing use of ecstasy in mind. It might be expected that with the increase in frequency of ecstasy use worldwide, ecstasy intoxication will become a frequent emergency even in pediatric and internal medicine clinical practice. The review on ecstasy intoxication treatment discloses the need to find specific antidotes instead of only having symptomatic treatment, which would be expected to enhance the quality of health care provided to these patients.

\section{ACKNOWLEGMENT}

H.M.T.B is the recipient of a CNPq $1 \mathrm{C}$ productivity grant.

\section{RESUMO}

MARISTELA F e col. - Intoxicação por êxtase: bases toxicológicas para o tratamento. Rev. Hosp. Clín. Fac. Med. S. Paulo 58(6):332-341, 2003.

Os jovens estão cada vez mais usando o 3,4-metilenodioximetanfetamina, conhecido como êxtase, pois acreditam que não causa danos. Entretanto, existem muitos relatos de efeitos adversos, incluindo a intoxicação aguda, abuso potencial e possíveis efeitos neurotóxicos. Portanto, profissionais da área da saúde necessitam reconhecer prontamente os sintomas da intoxicação a fim de iniciar o tratamento o mais breve possível. A droga é usada via oral durante várias horas de festas com danças. Agudamente, o êxtase aumenta a liberação do serotonina e diminui sua recaptação, levando a hipertensão, hipertermia, trismo e vômitos. Há discussão se as doses recreacionais causam danos permanentes aos neurônios serotonérgicos em humanos. Os usuários apresentam risco elevado de desenvolver distúrbios psicopatológicos, além disso, o uso prolongado pode induzir a dependência, caracterizada pela tolerância e ressaca. A intoxicação aguda necessita de trata- mento de emergência, para se evitar reações adversas e complicações graves. Não há antidotos específicos para tratar a intoxicação aguda. Medidas de suporte e tratamento médico para cada uma das complicações devem ser executados, mantendo-se em mente que os sintomas a serem tratados originamse principalmente do sistema nervoso central e do sistema cardiovascular.

DESCRITORES: 3,4-metilenodioximetanfetamina. Efeitos adversos. Desordens relacionadas a substância. Cognição. Hipertermia. 


\section{REFERENCES}

1. Substance Abuse and Mental Health Services Administration (SAMHSA). The NHSDA Report: Ecstasy use, March 21, 2003. Available at: http:// www.drugabusestatistics.samhsa.gov).

2. Carlini EA, Galduróz JCF, Noto RA, et al. I Levantamento Domiciliar sobre o Uso de Drogas Psicotrópicas no Brasil: Estudo envolvendo as 107 Maiores Cidades do País -2001. São Paulo, CEBRID - Centro Brasileiro de Informações Sobre Drogas Psicotrópicas, UNIFESP - Universidade Federal de São Paulo, 2002. p. 380.

3. Laranjeira R, Dunn J, Rassi R, et al. Êxtase (3,4 metilenodioximetanfetamina, MDMA): uma droga velha e um problema novo? ABP-APAL 1996; 18(3): 77-81.

4. Liechti ME, Vollenweider FX. Acute psychological and physiological effects of MDMA ("Ecstasy") after haloperidol pretreatment in healthy humans. Eur Neuropsychopharmacol 2000; 10(4): 289-295.

5. De La Torre R, Farré M, Mas M, et al. Non-linear pharmacokinetics of MDMA ("ecstasy") in humans. Br J Clin Pharmacol 2000; 49:104-109.

6. Muniesa H, Royo P. Hepatitis aguda tras consumo de éxtasis. Rev Esp Enf Digest 1995; 87(9): 681-683.

7. Shaper AG. Walking on the moon. Lancet 1996; 347: 207-208.

8. Downing J. The psychological and physiological effects of MDMA on normal volunteers. J Psychoactive Drugs 1986; 18(4): $335-$ 340 .

9. Greer G, Tolbert R. Subjective reports of the effects of MDMA in a clinical setting. J Psychoactive Drugs 1986; 18(4): 319-327.

10. Nichols DE. Differences between the mechanism of action of MDMA, MBDB, and the classic hallucinogens. Identification of a new therapeutic class: entactogens. J Psychoactive Drugs 1986; 18(4): 305-313.

11. Morgan MJ. Ecstasy (MDMA): a review of its possible persistent psychological effects. Psychopharmacology 2000; 152: 230248.

12. Buffu J, Moser C. MDMA and human sexual function. J Psychoactive Drugs 1986; 18(4): 355-359.

13. Mckenna DJ, Peroutka SJ. Neurochemistry and Neurotoxicity of 3,4-Methylenedioxymethamphetamine (MDMA, "Ecstasy"). J Neurochem 1990; 54:14-22.

14. DSM-IV. Manual Diagnóstico e Estatístico de Transtornos Mentais, 4 ed. Porto Alegre, Artes Médicas, 1995. p.175-272.

15. Liester M, Grob C, Bravo G, et al. Phenomenology and sequelae of 3,4-methylenedimethoxymethamphetamine use. J Nerv Ment Dis 1992; 180:345-352.

16. Ferigolo M, Medeiros FB, Barros HMT. "Êxtase": revisão farmacológica. Rev Saúde Pública 1998; 32(5): 487-95.

17. De Almeida SP, Silva MT. History, effects and mechanisms of action of ecstasy (3,4-methylenedioxyamphetamine): review of the literature. Rev Panam Salud Publica 2000; 8(6): 393402 .
18. Baptista MC. O uso de êxtase (MDMA) na cidade de São Paulo e imediações: um estudo etnográfico. São Paulo, 2002. (Dissertação (mestrado) - Escola Paulista de Medicina da Universidade Federal de São Paulo).

19. Pedersen W, Skrondal A. Ecstasy and new patterns of drug use: a normal population study. Addiction 1999; 94(11): 1695-1706.

20. Strote J, Lee JE, Wechsler H. Increasing MDMA use among college students: results of a national survey. J Adolesc Health 2002; 30: $64-72$

21. Klitzman RL, Greenberg JD, Pollack LM, et al. MDMA ('ecstasy') use, and its association with high risk behaviors, mental health, and other factors among gay/bisexual men in New York City. Drug Alcohol Depend 2002; 66: 115-125.

22. Mascaró BI, Aznar BA, Serrano GJ, et al. MDMA «Extasis»: Revisión Y Puesta Al Día. Rev Esp Drogodep 1991; 16(2): 91101.

23. Green AR, Cross AJ, Goodwin GM. Review of the pharmacology and clinical pharmacology of 3,4-methylenedioxymethamphetamine (MDMA or "Ecstasy"). Psychopharmacology 1995; 119: $247-260$

24. Steele TD, McCann UD, Ricaurte GA. 3,4- methylenedioxymethamphetamine (MDMA, "Ecstasy"): pharmacology and toxicology in animals and humans. Addiction 1994; 89: 539-551.

25. Greer G, Strassman R. Information on "ecstasy". Am J Psychiatry $1985 ; 142: 1391$

26. Grispoon L, Bakalar J. Can drug are used to enhance the psychotherapeutic process? Am J Psychoter 1986; 40: 393404.

27. Peroutk AS. Incidence of recreational use of 3,4-methylenedimethoxymethamphetamine (MDMA, "Ecstasy") on an Undergraduate campus. N Engl J Med 1987; 317: 1542-1543.

28. Dowling G, McDonough E, Bost R. "Eve" and "ecstasy": a report of five deaths associated with the use of MDEA and MDMA. JAMA 1987; 257: 1615-1617.

29. Tacke E - Hallucinogens In: CIRAULO DA, SHADER RI - Clinical Manual of Chemical Dependence. Washington, American Psychiatric Press, 1991. p. 259-278.

30. Russel A, Schwartz R, Dawling S. Accidental ingestion of "ecstasy" (3,4-methylenedimethoxymethamphetamine). Arch Dis Child 1992; 67: 1114-1115.

31. Shearman JD, Chapman RWG, Satsangi J, et al. Misuse of Ecstasy. BMJ 1992; 305: 309-310.

32. Brown C, Osterloh J. Multiple severe complications from recreational ingestion of MDMA ("Ecstasy"). JAMA 1987; 258:780-781.

33. Henry J. Ecstasy and the dance of death. BMJ 1992; 305: 5-6.

34. Siegel RK. MDMA nonmedical use and intoxication. J Psychoactive Drugs 1986; 18(4): 349-354. 
35. Wolff CK, Hay A, Sherlock K, et al. Contents of "ecstasy". Lancet 1995; 346: 1100-1101.

36. Weir E. Raves: a review of the culture, the drugs and the prevention of harm. CMAJ 2000; 162(13): 1829-30.

37. Randall T. Ecstasy-fueled "rave" parties become dances of death for English youths. J Am Med Assoc 1992; 268(12): 15051506.

38. Sydow K, Lieb R, Pfister H, et al. Use, abuse and dependence of ecstasy and related drugs in adolescents and young adults - a transient phenomenon? Results from a longitudinal community study. Drug Alcohol Depend 2002; 66: 147-159.

39. Riley SCE, James C, Gregory D, et al. Patterns of recreational drug use at dance events in Edinburg, Scotland. Addiction 2001; 96: 1035-1047.

40. Cuomo M.J, Dyment PG, Gammino VM. Increasing use of "ecstasy" (MDMA) and other hallucinogens on a college campus. J Am Coll Health 1994; 42(6): 271-274.

41. Reccia L, Rocco A, Lioniello M, et al. Amphetamine misuse in southern Italy. BMJ 1995; 311: 1433.

42. Cami J, Del Al Torre R, Ortuño J, et al. Pharmacokinetics of ecstasy (MDMA) in healthy subjects. In: Congress of the European Association for Clinical Pharmacology and Therapeutics, $2^{\text {nd }}$ Berlin, Germany, 1997. Eur J Clin Pharmacol 1997; 52 (Suppl.). p. 168.

43. Verebey K, Alrazi J, Jafre JH. The complications of "ecstasy" (MDMA). JAMA 1988; 259: 1649-1650.

44. Olson KR. POISONING, DRUG OVERDOSE. In: BENOWITZ Nl - Amphetamines. California, Appleton \& Lange, 1990. p. 62-64.

45. Gold MS, Miller NS. Intoxication and Withdrawal from Marijuana, LSD and MDMA. In: Miller NS, Gold MS, Smith DE - Manual of Therapeutics for Addictions. New York, Wiley-Liss, 1997. p. 51-54.

46. Morland J. Toxicity of drug abuse-amphetamine designer drugs (ecstasy): mental effects and consequences of single dose use. Toxicol Lett 2000; 112-113: 147-152.

47. Mcguire P, Cope H, Fahy T. Diversity of psychopathology associated with use of 3,4-methylenedimethoxymethamphetamine ("ecstasy"). Br J Psychiatry 1994; 165: 391395.

48. Mccann U, Ricaurte G. Lasting neuropsychiatric sequelae of methylenedioxymethamphetamine ("ecstasy") in recreational users. J Clin Psychopharmacol 1991; 11: 302-305.

49. Mcguire P, Fahy T. Chronic paranoid psychosis after misuse of MDMA ("ecstasy"). BMJ 1991; 302: 697.

50. Whitaker-Azmitia P, Aronson T. "Ecstasy" (MDMA) - Induced panic. Am J Psychiatry 1989; 146: 119.

51. Milas M. Acute psychosis with aggressive behavior as a consequence of MDMA (Ecstasy) consumption. Lijec Vjesn 2000; 122(1-2): 27-30.
52. Schifano F. Potential human neurotoxicity of MDMA ('Ecstasy'): subjective self-reports, evidence from an Italian drug addiction centre and clinical case studies. Neuropsychobiology 2000; 42(1): 25-33.

53. Bone Pina I, Ramos Gorostiza P, Villalba Yllan P, et al. Persisting and late onset psychotic disorder due to consumption of ecstasy (MDMA). Actas Esp Psiquiatr 2000; 28(1): 61-65.

54. Gamma A, Buck A, Berthold T, et al. No difference in brain activation during cognitive performance between ecstasy $(3,4$ methylenedioxymethamphetamine) users and control subjects: a [H2(15)O]-positron emission tomography study. Clin Psychopharmacol 2001; 21(1): 66-71.

55. Curran HV, Travill RA. Mood and cognitive effects of $+/-3,4$ methylenedioxymethamphetamine (MDMA, 'ecstasy'): weekend 'high' followed by mid-week low. Addiction 1997; 92(7): 821-831.

56. Peroutka S. "Ecstasy": a human neurotoxin? Arch Gen Psychiatry 1989; 46(2): 191.

57. Hayner GN, McKinney H. MDMA the dark side of ecstasy. J Psychoactive Drugs 1986; 18: 341-347.

58. Parrott AC. Human research on MDMA (3,4-methylenedioxymethamphetamine) neurotoxicity: cognitive and behavioural indices of change. Neuropsychobiology 2000; 42(1): $17-24$.

59. Rodgers J. Cognitive performance amongst recreational users of “ecstasy". Psychopharmacology 2000; 151(1): 19-24.

60. Wareing M, Fisk JE, Murphy PN. Working memory deficits in current and previous users of MDMA ('ecstasy'). Br J Psychol 2000; 91(2): 181-188.

61. Gouzoulis-Mayfrank E, Daumann J, Tuchtenhagen F, et al. Impaired cognitive performance in drug free users of recreational ecstasy (MDMA). J Neurol Neurosurg Psychiatry 2000; 68(6): 719-725.

62. Mccann UD, Eligulashvili V, Ricaurte GA. (+/-)3,4-Methylenedioxymethamphetamine ('Ecstasy')-induced serotonin neurotoxicity: clinical studies. Neuropsychobiology 2000; 42(1): $11-16$

63. Verkes RJ, Gijsman HJ, Pieters MS, et al. Cognitive performance and serotonergic function in users of ecstasy. Psychopharmacology 2001; 153 (2):196-202.

64. Mccann UD, Mertl M, Eligulashvili V, et al. Cognitive performance in (+/-) 3,4-methylenedioxymethamphetamine (MDMA, "ecstasy") users: a controlled study. Psychopharmacology 1999; 143(4): 417-25.

65. Marona-Lewicka D, Rhee G, Sprague J, et al. Reinforcing effects of certain serotonin-releasing amphetamine derivatives. Pharmacol Biochem Behav 1996; 53(1): 99-105.

66. Shulgin AT. The background and chemistry of MDMA. J Psychoactive Drugs 1986; 18(4): 291-304.

67. Ricaurte GA, Yuan J, Mccann UD. (+/-)3,4-Methylenedioxymethamphetamine ('Ecstasy')-induced serotonin neurotoxicity: studies in animals. Neuropsychobiology 2000; 42(1): $5-10$ 
68. Buchert R, Thomasius R, Nebeling B, et al. Long-term effects of "ecstasy" use on serotonin transporters of the brain investigated by PET. J Nucl Med 2003; 44 (3): 375-84.

69. Liechti ME, Gammma A, Vollenweider FX. Gender differences in the subjective effects of MDMA. Psychopharmacology 2001; 154: 161-168.

70. Marsh JCW, Abboudi ZH, Gibson FM, et al. Aplastic anaemia following exposure to 3,4-methylenedioxymethamphetamine (“Ecstasy"). Br J Haematol 1994; 88: 281-285.

71. Screaton GR, Singer M, Cairns HS, et al. Hyperpyrexia and rhabdomyolysis after MDMA (ecstasy) abuse. Lancet 1992; 339: 677-678
72. Squier M, Jalloh S, Hilton-Jones D, et al. Death after ecstasy ingestion: neuropathological findings. J Neurol Neurosurg Psychiatry 1995; 58: 756.

73. HENRY J, JEFFREYS K, DAWLING S. Toxicity and deaths from 3,4-methylenedioxymethamphetamine ("ecstasy"). Lancet 1992; 340: 384-387.

74. Mechan AO, O'shea E, Elliott JM, et al. A neurotoxic dose of 3,4methylenedioxymethamphetamine (MDMA, ecstasy) to rats results in a long-term defect in thermoregulation. Psychopharmacology 2001; 155 Issue 4: 413-418. 